\title{
Expression of binding of plasminogen, thrombospondin, vitronectin, and fibrinogen, and adhesive properties by Escherichia coli strains isolated from patients with colonic diseases
}

\author{
W Shen, H Steinrück, Å Ljungh
}

\begin{abstract}
Escherichia coli strains isolated from patients with colonic disorders $(n=27)$ and strains isolated from the rectal mucosa of healthy subjects $(n=24)$ were compared with respect to expression of cell surface hydrophobicity, carriage of intestinal virulence factors, adhesion to tissue culture cells, and expression of binding of extracellular matrix proteins and plasma proteins. Strains isolated from patients with colonic disease did not express a more hydrophobic cell surface than strains from healthy subjects. Few strains from both groups carried genes encoding for recognised virulence factors of $E$ coli. Only one strain, carrying the eae gene induced actin polymerisation in tissue culture cells. Strains from patients with colonic diseases adhered to HT29 cells, which are of intestinal origin, to a higher extent than $E$ coli from healthy subjects. Significantly more strains from patients with colonic disorders than $E$ coli from healthy subjects expressed binding of fibronectin, collagens, laminin, vitronectin, plasminogen, throbospondin, and fibrinogen. Expression of binding of these proteins may influence the pathogenesis of colonic disease by mediating binding to ulcerated tissue, preventing complement induced lysis of bacteria and by exerting proteolytic activity. There was no correlation between serotype, expression of cell surface hydrophobicity, and binding of extracellular matrix and plasma proteins. (Gut 1995; 36: 401-406)
\end{abstract}

Keywords: $E$ coli, colonic disease, protein binding expression, adhesive properties.

Ulcerative colitis is a chronic, relapsing disease usually affecting the distal colon. The aetiology of the disease and causes of exacerbations are still unknown. Because of the resemblance to infectious colitis, several attempts have been made to link a microbial agent to ulcerative colitis, such as the invasive organisms Shigella sp, Salmonella sp, and Campylobacter jejuni. ${ }^{1}$ Also toxin producing bacteria such as Clostridium difficile have been isolated in connection with relapse of ulcerative colitis. ${ }^{2}$ Shiga like toxin (Vero toxin) producing Escherichia coli were isolated from some patients during relapse and may have aggravated the symptoms ${ }^{3-7}$ but shiga like toxin producing $E$ coli were not more frequently isolated from rectal biopsy specimens of patients with ulcerative colitis than from healthy subjects. ${ }^{4}$ No bacterial species has been linked conclusively to the disease.

One hydrophobic adhesin mediating adhesion to buccal cells was described by Burke and Axon. ${ }^{9}$ In contrast, strains isolated from rectal biopsy specimens of patients with ulcerative colitis did not express higher cell surface hydrophobicity than strains isolated from the rectal mucosa of healthy subjects. ${ }^{6}$

A number of virulence factors have been described in $E$ coli causing infection of the small intestine, such as enterotoxins, fimbrial adhesins, and outer membrane proteins of non-fimbrial nature. ${ }^{10}$ Very few virulence factors of $E$ coli causing colitis have been characterised. Apart from the classic enteroinvasive $E$ coli, where the invasive ability is conferred by a $140 \mathrm{kDa}$ plasmid, enteropathogenic $E$ coli strains have been shown to possess invasive ability. ${ }^{11-13}$ Interestingly, immotile, shigella like $E$ coli were more commonly isolated from patients than from healthy subjects, though the difference was not statistically significant. ${ }^{6} 14$ Whether these strains have invasive properties is under investigation.

We have previously shown that strains from patients with ulcerative colitis commonly express binding of fibronectin, collagen type I, and laminin. 467 These extracellular matrix proteins are certainly exposed in colonic ulcers during a relapse of ulcerative colitis, and expression of binding of these proteins could represent a mechanism for anchoring bacteria in the tissue. Whether these proteins are also exposed in non-ulcerated colonic mucosa has not been elucidated. The link protein of colonic mucus was proposed to be an Fn fragment but this has not been confirmed. ${ }^{15}$

This study was undertaken to analyse expression of binding of vitronectin, plasminogen, thrombospondin, and fibrinogen by $E$ coli strains isolated from rectal biopsy specimens of patients with ulcerative colitis and other colonic diseases and healthy subjects, and to further investigate adhesive properties of these strains.

\section{Methods}

\section{BACTERIAL STRAINS}

$E$ coli strains isolated as the dominating strain from rectal biopsy specimens of patients with relapse of ulcerative colitis $(n=20)$, Crohn's disease $(n=2)$, colitis and proctitis of unknown 
cause $(n=5)$, and from rectal mucosa of healthy subjects $(n=24)$ were studied. The strains were serotyped according to Örskov and Örskov. ${ }^{16} E$ coli E2348 was used as control in phalloidin staining. Strains were stored in tryptic soy broth with glycerol $(20 \% \mathrm{w} / \mathrm{v})$ at $-80^{\circ} \mathrm{C}$. Unless otherwise stated strains were cultured on colonisation factor agar at $37^{\circ} \mathrm{C}$ overnight. $^{17}$

\section{CELL SURFACE HYDROPHOBICITY}

The cell surface hydrophobicity was determined by the salt aggregation test as earlier described. ${ }^{18}$ The highest dilution of ammonium sulphate (final concentration) in which visible aggregation occurred is the salt aggregation test value.

\section{PROTEIN BINDING}

Vitronectin, fibrinogen, thrombospondin, plasminogen (Glu-Plg and Lys-Plg), fibronectin, collagen type I and IV, and laminin were radiolabelled with Iodobeads ${ }^{19}$ to a specific activity of around $4 \times 10^{6} \mathrm{cpm} / \mu \mathrm{g}$ protein. One hundred $\mu l$ of washed bacterial cells $\left(7 \times 10^{7}\right)$ in phosphate buffered saline $(0.02 \mathrm{M}$ sodium phosphate buffer, $\mathrm{pH} 6.8$ in $0 \cdot 15 \mathrm{M} \mathrm{NaCl}$ ) was mixed with $100 \mu \mathrm{l}$ (about $25000 \mathrm{cpm}$ ) of ${ }^{125}$ I-labelled protein in phosphate buffered saline. Measurement of expression of binding was performed as previously described. ${ }^{2021}$ Results are expressed as mean values of duplicate samples, and represent amount of bound protein in percentage of total amount of added labelled protein. Less than $10 \%$ binding is considered negative, $10-15 \%$ binding low, $15-40 \%$ binding moderate, and $>40 \%$ binding as high binding. $E$ coli NG7C was included as positive control and strain PSS 1 as negative control. ${ }^{20}$

\section{HYBRIDISATION}

Colony blot hybridisation was performed with genes encoding for attachment effacing (eae) and enteropathogenic $E$ coli adherence factor, (EAF), and synthetic oligonucleotides for heat labile and heat stable enterotoxins, shiga like toxin I and II, and enteroinvasivity (the 140 $\mathrm{kDa}$ plasmid). ${ }^{22}$ Hybridisation was performed under stringent conditions.

\section{ADHESION TESTS}

Strains were tested for adhesion to HT29 and HeLa cells according to Cravioto et al. ${ }^{23}$ Subconfluent monolayers of tissue culture cells on $13 \mathrm{~mm}$ diameter glass cover slips were placed in multiwell tissue culture plates with 1 ml HEPES buffered minimal essential medium with $5 \%$ fetal calf serum and $0.5 \% \mathrm{D}$-mannose. Ten $\mu l$ of an overnight colonisation factor broth culture of bacterial strains was added to each well and incubated for three hours at $37^{\circ} \mathrm{C}$ in $5 \%$ carbon dioxide. The cover slips were washed three times in phosphate buffered saline and fixed for 20 minutes in 3\% formalin. The number of adhering bacteria to at least 200 cells was counted. The data were expressed as mean values. To study the effect on the cytoskeleton, strains were incubated with HEp-2 cells and HT29 cells and stained with phalloidin as described by Knutton et al. ${ }^{24}$

\section{CHEMICALS}

Vitronectin was purified according to Yatohgo et $a l^{25}$ and fibronectin according to Vuento and Vaheri. ${ }^{26}$ Lys-plasminogen and glu-plasminogen were gifts from Dr U Hedner, Novo AS, Copenhagen, Denmark, thrombospondin from Dr J Lawler, Boston, USA, and laminin from Dr K H Valkonen, University of Oulu, Oulu, Finland. Collagen type I was purchased from Collagen Research, Palo Alto, CA, USA, and collagen type IV from Heyl AG, Germany. Agar bases were purchased from LabM, Salford, United Kingdom, fibrinogen from KABIPharmacia, Uppsala, Sweden, Iodobeads from Amersham International, Amersham, United Kingdom, phalloidin, Tween 20 and bovine serum albumin from Sigma Chemical, St Louis, MO, USA, and gentamicin from Schering Plough, Kenilworth, NJ, USA, tryptic soy broth was from Difco Laboratories, Detroit, MI. Salts were from Merck AG, Darmstadt, Germany. Tissue culture media were from Flow Laboratories, Rickmansworth, United Kingdom. All chemicals were of analytical grade.

\section{STATISTICAL ANALYSES}

The Mann-Whitney unpaired non-parametric test was used for statistical analysis.

\section{Results}

Most of the strains isolated from healthy subjects expressed moderate cell surface hydrophobicity (salt aggregation test $0 \cdot 5-1 \cdot 6$, Table I) whereas most of the strains isolated from patients with inflammatory bowel disease or other colonic disorders expressed low surface hydrophobicity (salt aggregation test 2 or $>2$, Table I).

The strains isolated from patients with colonic disorders expressed binding of the proteins to a high extent and only three strains did not bind any of the proteins (Figure, Table II). There was no significant difference in binding of Lys-plasminogen or Glu-plasminogen. The highest degree of binding was of fibrinogen in that 14 strains expressed high binding, 10 moderate binding, one low binding, and three strains did not bind fibrinogen. The lowest degree of binding was with vitronectin. Two strains from patients with colonic disease expressed high binding, 17 moderate binding, four strains low binding, and five strains did not bind vitronectin. Six strains bound thrombospondin to a high degree, and two strains plasminogen. In contrast, two strains isolated from healthy rectal mucosa expressed high binding of fibrinogen, one of thrombospondin, and 18 strains did not bind any of the proteins tested. The difference in expression of binding between patients with colonic disorders and 
TABLE I Characteristics of E coli strains

\begin{tabular}{|c|c|c|c|c|c|c|}
\hline \multirow[b]{2}{*}{ Strain } & \multirow[b]{2}{*}{ Diagnosis } & \multirow[b]{2}{*}{ Serotype } & \multirow{2}{*}{$\begin{array}{l}\text { Hybridisation } \\
\text { with probe }\end{array}$} & \multirow[b]{2}{*}{$\mathrm{CSH}^{\star}$} & \multicolumn{2}{|c|}{ Adhesion to cells† } \\
\hline & & & & & $\mathrm{HeLa}$ & HT29 \\
\hline RL3 & UC & $\mathrm{ND}^{3}$ & & 2 & ND & ND \\
\hline $\mathrm{RLA}$ & UC & O8:H- & & $>2$ & 5 & 10 \\
\hline RL10 & UC & O119:H54 & & 2 & 17 & 15 \\
\hline RL36 & UC & O143:H4 & & $>2$ & 12 & 5 \\
\hline RL41 & UC & ONT:H27 & & $>2$ & 7 & 5 \\
\hline RL49 & UC & O18:K1:H7 & & $>2$ & 5 & 5 \\
\hline RL50 & UC & $\mathrm{O} 1: \mathrm{H}-$ & & 2 & 5 & 5 \\
\hline RL51 & UC & $\mathrm{O} 1: \mathrm{H} 4$ & SLTI & $>2$ & 100 & 100 \\
\hline RL64 & Crohn's disease & $\mathrm{O} 7: \mathrm{H} 4$ & SLTI & $>2$ & 35 & 5 \\
\hline RL65 & Proctitis & $\mathrm{O} 7: \mathrm{H} 4$ & & $>2$ & 12 & 25 \\
\hline RL66 & UC & $\mathrm{O} 2: \mathrm{K} 1: \mathrm{H} 7$ & SLTI, eae & 2 & 35 & 15 \\
\hline RL70 & UC & $\mathrm{O} 23: \mathrm{H}-$ & & $>2$ & 35 & 15 \\
\hline RL74 & UC & $\mathrm{O} 12: \mathrm{H} 19$ & & $\overline{1}$ & 25 & 10 \\
\hline RL78 & Crohn's disease & ONT:H37 & SLTI & 2 & 7 & 5 \\
\hline RL81 & IBD & $\mathrm{O} 7: \mathrm{H} 4$ & & $>2$ & 25 & 25 \\
\hline RL90 & UC & O23:H16 & SLTI & 2 & 5 & 25 \\
\hline RL92 & Colitis & O53:H7 & & $>2$ & 12 & 15 \\
\hline RL96 & UC & $\mathrm{O} 7: \mathrm{H} 15$ & & 2 & 12 & 10 \\
\hline RL99 & UC & O86:K5:H10 & SLTI+II & $>2$ & 25 & 25 \\
\hline RL100 & UC & ONT:H26 & SLTI & $>2$ & 12 & 10 \\
\hline RL109 & UC & $\mathrm{O} 23: \mathrm{H} 16$ & & $>2$ & 35 & 40 \\
\hline RL110 & Colitis & ONT:H- & & $>2$ & 15 & 15 \\
\hline RL114 & UC & $\mathrm{O} 7: \mathrm{H} 4$ & SLTII & $>2$ & 7 & 15 \\
\hline RL118 & UC & O159:H4 & & $>2$ & 12 & 15 \\
\hline RL129 & Colitis & $\mathrm{O} 2: \mathrm{H}-$ & & $\overline{1}$ & 35 & 25 \\
\hline RL131 & Proctitis & O99:H53 & SLTI & 0.5 & 35 & 15 \\
\hline Ec 40 & UC & O147:H21 & & $1 \cdot 6$ & ND & ND \\
\hline Ec 44 & Healthy & $\mathrm{O} 20$ & & $>2$ & ND & ND \\
\hline Ec 53 & Healthy & O77:H? & & $>2$ & 7 & 5 \\
\hline Ec 54 & Healthy & $\mathrm{O} 6: \mathrm{H}-$ & & $0 \cdot 1$ & 6 & 8 \\
\hline Ec 71 & Healthy & O8:H10 & & $>2$ & 7 & 15 \\
\hline Ec 76 & Healthy & O8:K42 & & $>2$ & 5 & 10 \\
\hline Ec 80 & Healthy & $\mathrm{O} 121$ & & 1.6 & 5 & ND \\
\hline Ec 102 & Healthy & O83:H? & & 0.9 & 27 & 15 \\
\hline Ec 107 & Healthy & O101:K103:H9 & & 1.6 & 8 & 9 \\
\hline Ec 109 & Healthy & $\mathrm{O} 7: \mathrm{K} 1$ & & 1.6 & 7 & 5 \\
\hline Ec 110 & Healthy & $\mathrm{O} 20,133: \mathrm{H}-$ & & 1.6 & 24 & 23 \\
\hline Ec 111 & Healthy & $\mathrm{O} 1: \mathrm{K} 1: \mathrm{H}-$ & & 1.6 & 12 & 15 \\
\hline Ec 115 & Healthy & $\mathrm{O} 2$ & & 0.9 & 5 & 5 \\
\hline Ec 116 & Healthy & $\mathrm{O} 25: \mathrm{H}$ rough & & $0 \cdot 1$ & 22 & 15 \\
\hline Ec 118 & Healthy & $\mathrm{O} 50: \mathrm{H} 5$ & & 0.9 & 25 & 0 \\
\hline Ec 119 & Healthy & O7 & & $>2$ & 17 & 10 \\
\hline Ec 120 & Healthy & O8 & & $<0 \cdot 1$ & 100 & 5 \\
\hline Ec 121 & Healthy & $\mathrm{O} 154: \mathrm{H} 4$ & & $>2$ & 12 & 5 \\
\hline Ec 127 & Healthy & O18ac, 53 & & 0.9 & 22 & 5 \\
\hline Ec 138 & Healthy & $\mathrm{O} 2: \mathrm{K} 51: \mathrm{H} 7$ & & 1.6 & 100 & 25 \\
\hline Ec 140 & Healthy & O8:K29:H- & & $>2$ & 12 & 10 \\
\hline Ec 148 & Healthy & O40 & SLTI & 1.6 & 17 & 10 \\
\hline Ec 151 & Healthy & $\mathrm{O} 2: \mathrm{H} 7$ & & 1.6 & 100 & 10 \\
\hline Ec 152 & Healthy & O87:H19 & & $>2$ & ND & ND \\
\hline Ec194 & Healthy & $0112 a b$ & & 1.6 & 18 & 10 \\
\hline
\end{tabular}

${ }^{\star} \mathrm{CSH}=$ cell surface hydrophobicity as determined by salt aggregation test. $\uparrow$ Number of bacterial cells/tissue culture cell. $\mathrm{ND}=$ not done; $\mathrm{IBD}=$ inflammatory bowel disease; $\mathrm{UC}=$ ulcerative colitis.

healthy persons was highly significant $(\mathrm{p}<0.001)$.

Also, binding of fibronectin, collagen type I and IV, and laminin was more common among strains isolated from patients with colonic disorders than from healthy subjects $(p<0.001)$ (Figure, Table II). Although several strains expressed binding of more than one protein, and some strains did not bind any protein, expression of binding of the different extracellular matrix proteins and fibrinogen does not seem to be coregulated.

There was no correlation between either serotype or cell surface hydrophobicity and binding of the different proteins. The number of patients in the ulcerative colitis group was too small to permit correlations between expression of protein binding and activity of disease.

One strain isolated from a patient with ulcerative colitis adhered at high numbers (100 bacteria/cell) to HT29 as well as to HeLa cells, and three strains from healthy subjects adhered at high numbers to $\mathrm{HeLa}$ cells but not to HT29 cells (Table I). There was a poor correlation between adhesion to HeLa and HT29 cells. Strains from ulcerative colitis patients, however, adhered at significantly higher numbers per cell to HT29 cells than strains from healthy subjects $(p=0.0199)$. There was no correlation between expression of cell surface hydrophobicity and adhesion to either tissue culture cell line. Nor was there any correlation between serotype and adhesion to the cell lines.

Thirteen strains were stained with phalloidin after incubation with HEp 2 and HT29 cells. Only strain RL66, which hybridises with probes for eae and SLTII gave the typical accumulation of actin in HEp-2 cells. The staining of HT29 cells was less pronounced but all strains except one induced changes in the cells. After incubation with one strain of serotype O50, all cells were lysed. A typical finding was that there were no normal actin filament bundles in the cells.

No strain hybridised with the established $E$ coli virulence factors: heat labile or heat stable enterotoxins, invasivity plasmid or enteropathogenic $E$ coli adherence factor. One strain hybridised with eae, and seven strains isolated from patients with colonic illness with SLTI (Table I). One strain hybridised with the SLTII probe, and one strain with both SLTI and SLTII probes. One of the strains isolated from healthy rectal mucosa hybridised with the SLTI probe.

\section{Discussion}

Twenty years ago Cooke et al ${ }^{27}$ tried to link virulence properties of $E$ coli to the precipitation of relapse of ulcerative colitis. We subsequently described the isolation of shiga like toxin producing $E$ coli in patients with relapse of ulcerative colitis. ${ }^{37}$ This was later confirmed by others. ${ }^{5}$ In a study on the cause of infections and non-infectious colitis, the incidence of shiga like toxin producing $E$ coli was similar among strains isolated from rectal biopsy specimens of patients with a first episode of ulcerative colitis and with infectious colitis. ${ }^{28}$ In the same study very few strains were shown to carry the hitherto described virulence factors of $E$ coli. $^{28}$ This was to be expected as most of these virulence factors play a part in infections of the small intestine. Interestingly, enteropathogenic $E$ coli adherence factor and attachment effacement factor (eae) have been described to act both in the small and large intestine. ${ }^{29}$ In our study, only one strain from a patient with ulcerative colitis carried the eae gene, which shows that neither of these virulence factors are common in strains isolated from patients with inflammatory bowel disease. Our data, however, support the finding by Knutton et al that strains carrying eae induce actin accumulation in intestinal cells from both the small and large intestine. ${ }^{24}$

We have further found that $E$ coli strains producing haemolysin but not colicin were more commonly isolated from biopsy specimens of patients with ulcerative colitis than patients with infectious colitis. ${ }^{14}$ These strains may be similar to virulent Salmonella strains. ${ }^{30}$ The pathogenesis of ulcerative colitis and relapse of ulcerative colitis is probably multifactorial, but a subset of $E$ coli strains adhering 


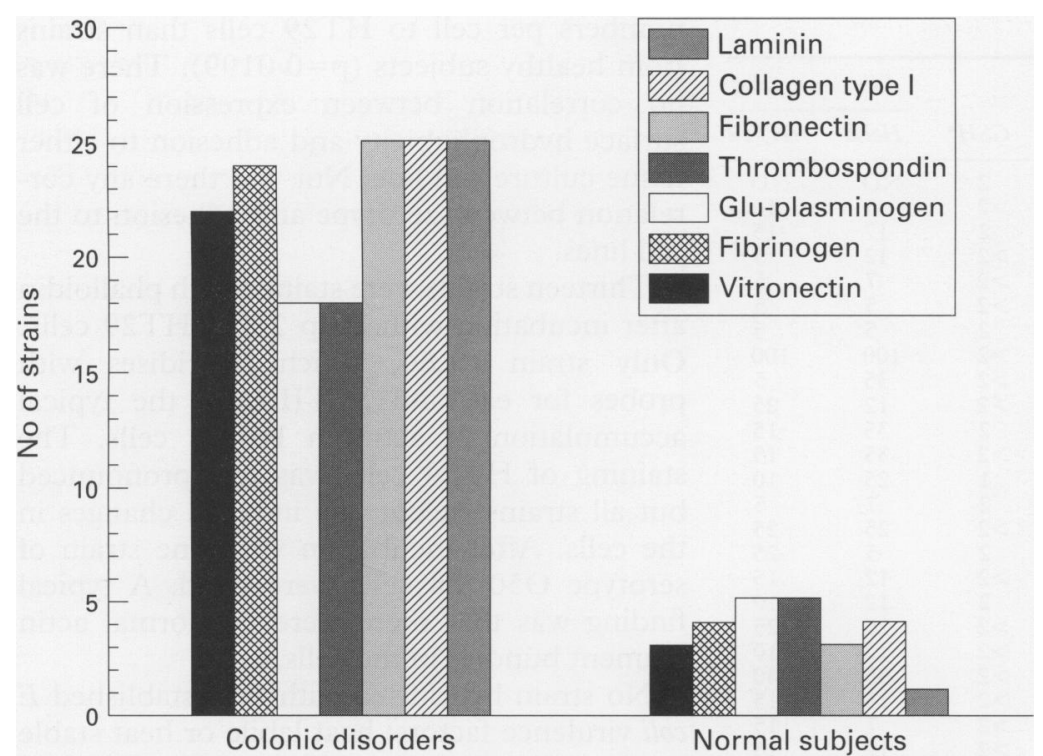

Number of $\mathrm{E}$ coli strains isolated from patients with colonic disorders and healthy subjects expressing binding of vitronectin, fibrinogen, Glu-plasminogen, thrombospondin, fibronectin, collagen type I, and laminin. extent than strains isolated from rectal biopsy specimens of patients with ulcerative colitis. ${ }^{6}$ The data in this study confirm our earlier findings.

Although only one of the strains isolated from patients with colonic diseases adhered to a great extent ( 100 bacterial cells/tissue culture cell) to HT29 cells and HeLa cells, and three strains from healthy subjects adhered to HeLa cells in high numbers, strains isolated from patients with colonic disorders adhered in significantly higher numbers to HT29 cells than strains from healthy subjects (Table I). $\mathrm{HeLa}$ cells are not of intestinal origin and HT29 cells are malignant intestinal cells, which may express surface structures differing from those of patients with ulcerative colitis as well as of healthy subjects. Similarly, the adhesion to buccal cells of strains isolated from patients with ulcerative colitis may not be relevant for adhesion to cells from the large intestine. ${ }^{89}$ The data on adhesiveness presented here, however, could show that adhesion plays a part in pathogenesis. This should be explored using colonic cells, preferably from patients with colonic disorders as well as from healthy subjects.

We have earlier shown that $E$ coli strains of intestinal and extraintestinal origin commonly bind fibronectin, collagen, and vitronectin. ${ }^{20}$ In a study of $E$ coli strains isolated from patients with ulcerative colitis and other colonic disorders most strains expressed binding of fibronectin, collagen, or laminin, or all three. ${ }^{4}$ The data in this study support these findings. In this study $E$ coli strains were further analysed for expression of binding of vitronectin, fibrinogen, thrombospondin, and plasminogen. Strains isolated from patients with colonic disorders expressed binding of

TABLE II Binding of fibronectin, collagen type I and IV, laminin, vitronectin, fibrinogen, thrombospondin, and plasminogen by selected $\mathrm{E}$ coli isolated from patients with ulcerative colitis and healthy subjects

\begin{tabular}{|c|c|c|c|c|c|c|c|c|c|}
\hline \multirow[b]{2}{*}{ Strain } & \multicolumn{9}{|c|}{ Percentage binding of } \\
\hline & Fibronectin & $\begin{array}{l}\text { Collagen } \\
\text { type I }\end{array}$ & $\begin{array}{l}\text { Collagen } \\
\text { type II }\end{array}$ & Laminin & Vitronectin & Fibrinogen & Thrombospondin & $\begin{array}{l}\text { Lys- } \\
\text { plasminogen }\end{array}$ & $\begin{array}{l}\text { Glu- } \\
\text { plasminogen }\end{array}$ \\
\hline RL4 & 70 & 78 & 70 & 60 & 3 & 4 & 3 & 5 & 7 \\
\hline RL10 & 76 & 76 & 76 & 73 & 50 & 80 & 60 & 45 & 37 \\
\hline RL36 & 19 & 20 & 24 & 23 & 8 & 23 & 9 & 6 & 10 \\
\hline RL41 & 14 & 33 & 34 & 31 & 23 & 47 & 46 & 34 & 33 \\
\hline RL499 & 54 & 46 & 52 & 36 & 19 & 58 & 37 & 28 & 26 \\
\hline RL50 & 50 & 44 & 16 & 16 & 1 & 3 & 4 & 2 & 5 \\
\hline RL66 & 55 & 60 & 43 & 43 & 14 & 64 & 16 & 11 & 12 \\
\hline RL74 & 18 & 26 & 20 & 18 & 11 & 30 & 4 & 5 & 7 \\
\hline RL78 & 29 & 35 & 23 & 23 & 12 & 41 & 47 & 33 & 30 \\
\hline RL81 & 37 & 39 & 49 & 33 & 12 & 25 & 13 & 6 & 10 \\
\hline RL90 & 53 & 64 & 49 & 44 & 16 & 69 & 3 & 4 & 5 \\
\hline RL96 & 39 & 51 & 41 & 25 & 17 & 30 & 38 & 13 & 15 \\
\hline RL99 & 32 & 48 & 28 & 35 & 14 & 47 & 18 & 7 & 9 \\
\hline RL100 & 54 & 43 & 43 & 34 & 13 & 39 & 35 & 14 & 15 \\
\hline RL109 & 14 & 32 & 24 & 16 & 10 & 23 & 17 & 12 & 8 \\
\hline RL110 & 13 & 30 & 25 & 28 & 11 & 44 & 10 & 8 & 10 \\
\hline RL118 & 44 & 46 & 35 & 29 & 10 & 50 & 50 & 28 & 25 \\
\hline RL129 & 3 & 2 & 3 & 9 & 49 & 63 & 73 & 51 & 40 \\
\hline Ec 40 & 7 & 8 & 6 & $<2$ & $<2$ & 2 & 3 & 2 & 3 \\
\hline Ec 53 & 22 & 4 & 2 & ND & 13 & 12 & 30 & 12 & 13 \\
\hline Ec 76 & $<2$ & $<2$ & $<2$ & 3 & 2 & $<2$ & $<2$ & $<2$ & 2 \\
\hline Ec 80 & $<2$ & $<2$ & $<2$ & 3 & $<2$ & 3 & 2 & $<2$ & 2 \\
\hline Ec 107 & $<2$ & $<2$ & $<2$ & $<2$ & $<2$ & $<2$ & $<2$ & $<2$ & $<2$ \\
\hline Ec 115 & $<2$ & $<2$ & $<2$ & $<2$ & 3 & 9 & 9 & 8 & 9 \\
\hline Ec 116 & $<2$ & $<2$ & $<2$ & $<2$ & 6 & 10 & 17 & 9 & 13 \\
\hline Ec 118 & $<2$ & $<2$ & $<2$ & ND & 24 & 55 & 52 & 34 & 30 \\
\hline Ec 127 & $<2$ & $<2$ & $<2$ & ND & 5 & 18 & 18 & 10 & 14 \\
\hline Ec 148 & 8 & 23 & 19 & ND & $<2$ & 4 & 4 & 2 & 5 \\
\hline Ec 151 & 36 & 41 & 36 & ND & 15 & 41 & 38 & 22 & 22 \\
\hline Ec 152 & 7 & 23 & 19 & ND & 5 & $<2$ & $<2$ & 3 & 3 \\
\hline Ec 194 & 3 & 17 & 12 & 12 & 3 & $<2$ & 3 & 5 & 6 \\
\hline
\end{tabular}

$\mathrm{ND}=$ not done. $>40 \%$ binding denotes high binding, $15-40 \%$ moderate binding, and $10-15 \%$ low binding. 
these proteins to a significantly higher extent than strains from healthy persons (Figure, Table II). This may be of relevance in the pathogenesis in different ways. Fibrinogen binding by Staphylococcus aureus is well known to induce fibrin formation and abscesses. Furthermore, fibrin is exposed in intestinal ulcers, hence expression of fibrinogen binding may mediate binding of $E$ coli to ulcers. Fibrinogen is a 'sticky' protein and the reported binding may not be caused by receptor specific interaction. The pathogenetic effects of binding, however - that is, transformation of fibrinogen to fibrin and adhesion to fibrin in ulcerated mucosa - will probably occur regardless of the character of the binding.

Vitronectin binds to complement factors C5-9 and inhibits polymerisation of C9.31 Whether vitronectin binding by bacteria interferes with this process has not been elucidated. Binding of vitronectin and other extracellular matrix proteins may represent a mechanism of protection from complement induced cell lysis, as earlier proposed for non-specific immunoglobulin binding to protein A of $S$ aureus, ${ }^{32}$ and hence enhance survival in tissues.

Plasminogen binding of $S$ aureus and streptococci has been described earlier. ${ }^{33} 34$ When Glu-plasminogen is bound to a bacterial surface it is converted to plasmin. In this form, it is protected from inactivation by inhibitors in plasma and may thus continue to exert proteolytic activity. Glu-plasminogen is more active than Lys-plasminogen. In the study by Ullberg et al, ${ }^{35} \mathrm{E}$ coli strains of non-intestinal origin did not express plasminogen binding. It is thus very interesting that most strains isolated from patients with colonic diseases expressed plasminogen binding. $E$ coli strains carrying S-fimbriae have been shown to form a complex with plasminogen, generating bacteria bound plasmin, which promoted bacterial invasion and contributed to systemic activation of fibrinolysis. ${ }^{36}$ If $E$ coli bind plasminogen also in the colonic epithelium and similar effects are obtained, proteolytic activity, which enhances epithelial invasion or fibrinolytic activity, or both should be explored.

Thrombospondin is an important platelet glycoprotein and also forms part of the extracellular matrix in response to inflammation and injury. $S$ aureus strains have earlier been shown to express binding of thrombospondin, ${ }^{37}$ and this was postulated to mediate adhesion of staphylococcal cells to surfaces. Microthrombi were shown to be prevalent in intestinal biopsy specimens of patients with ulcerative colitis. $^{38}$ Binding of thrombospondin may well interfere with platelet activation and formation of microthrombi, and also represent a mechanism of tissue adherence. This should be further explored in the pathogenesis of ulcerative colitis.

Expression of fibronectin binding by $E$ coli is enhanced in the presence of calcium ions and suppressed in the presence of increased salt concentration, and the growth medium influences expression of collagen, vitronectin, and laminin also. ${ }^{21}$ Whether or not the growth environment in the colonic epithelium enhances expression of extracellular matrix binding properties has not been studied. In this study, we show that strains isolated from patients with colonic disease have the ability to express binding of several extracellular matrix proteins and fibrinogen expression of binding of these proteins may enhance adhesion to colonic mucosa and contribute to tissue damage.

This study was supported by grants from the Swedish Medical Research Council (16x-09929), the Nanna Svartz Foundation, and the Royal Physiographic Society, Lund, Sweden. We gratefully acknowledge the kind gifts of plasminogen, thrombospondin, and laminin, as well as of oligonucleotides for enterotoxins and shiga like toxin I and II from Dr O Olsvik, CDC, Atlanta, GA, USA, and E coli E2348 from Dr S Knutton, CDC, Atlanta, GA, USA, and $E$ coli E2348 from Dr $S$ Knutt
University of Birmingham, Birmingham, United Kingdom.

1 Ljungh $\AA$. Microbiological aspects of inflammatory bowel disease. In Järnerot $G$, Lennard-Jones J, Truelove $S$, eds Inflammatory bowel disease. Malmö: Corona Press, 1992 73-89.

2 Meyers S, Mayer L, Bottone E, Desmond E, Janowitz H. Occurrence of Clostridium difficile toxin during the course of inflammatory bowel disease. Gastroenterology 1981; 80: 697-700.

3 Lungh Å, Eriksson M, Eriksson Ö, Henter J-I, Wadström T Shiga-like toxin production and connective tissue protein Shiga-like toxin production and connective tissue protein
binding of Escherichia coli isolated from a patient with binding of Escherichia coli isolated from a patient
ulcerative colitis. Scand $\mathcal{f}$ Infect Dis 1988; 20: 443-6.

4 Olusanya $\mathrm{O}$, Steinrück $\mathrm{H}$, Aleljung $\mathrm{P}$, Ascencio F, Curman B, Järnerot G, et al. Surface properties, connective tissue protein binding and Shiga-like toxin production of Escherichia coli isolated from patients with ulcerative colitis. Int f Med Microbiol 1992; 276: 254-63.

5 von Wulffen $H$, Russman $H$, Karch $H$. Verocytotoxinproducing Escherichia coli $\mathrm{O} 2: \mathrm{H} 5$ isolated from patients with ulcerative colitis. Lancet 1988; i: 1449-50.

6 Ljungh Å, Aleljung P, Malmer C, Selander B, Wadström T. Subepithelial connective-tissue protein binding in Escherichia coli isolated from patients with ulcerative colitis and healthy persons. Microbial Ecology and Therapy colitis and $1993 ; 21$.

7 Ljungh $\AA$, Wadström T. Subepithelial connective tissue protein binding of Escherichia coli isolated from patients with ulcerative colitis. In: McDermott RP, ed Inflammatory bowel disease: current status and future approach. Amsterdam: Elsevier Science, 1988: 571-5.

8 Giaffer $\mathrm{MH}$, Holdsworth CD, Duerden BI. Virulence properties of Escherichia coli isolated from patients with inflammatory bowel disease. Gut 1992; 33: 646-50.

9 Burke DA, Axon ATR. Hydrophobic adhesin of Escherichia coli in ulcerative colitis. Gut 1988; 29: 41-3.

10 Levine MM, Prado V, Robins-Browne R, Lior H, Kaper JB Moseley SL, et al. Use of DNA probes and HEp-2 cell adherence assay to detect diarrheagenic Escherichia coli. $\mathcal{f}$ Infect Dis 1988; 158: 224-8

11 Donnenberg MS, Donohue-Rolfe A, Keusch GT. Epithelial cell invasion an overlooked property of enteropathogenic Escherichia coli associated with the EPEC adherence factor. F Infect Dis 1989; 160: 452-9.

12 Andrade JRC, Da Veiga VF, Santa Rosa MR, Suassuna I. An endocytic process in HEp-2 cells induced by enteropathogenic Escherichia coli. $\mathcal{f}$ Med Microbiol 1989; 28: 49-57.

13 Fletcher JN, Embaye HE, Getty B, Batt RM, Hart CA Saunders JR. Novel invasion determinant of enteropathogenic Escherichia coli plasmid pLV501 encodes the ability genic Escherichia coli plasmid pLV501 encodes the ability
to invade intestinal epithelial cells and HEp-2 cells. Infect to invade intestinal epithelial

14 Schumacher G, Steinrück H, Geyid A, Kollberg B, Ljungh $\AA$. Virulence properties of Escherichia coli isolated from the rectal mucosa of patients with first attacks of colitis Microbial Ecology in Health and Disease (in press).

15 Slomiany A, Okazaki K, Tamura S, Slomiany BL. Identity of mucin's '118-kDa link protein' with fibronectin fragment. Arch Biochem Biophys 1991; 286: 383-8.

16 Örskov F, Örskov I. Serotyping of Escherichia coli. In: Bergan T, Norris JR, eds. Methods of microbiology. Bergan T, Norris JR, eds. Methods of
London: Academic Press, 1978; 14: 1-77.

17 Evans DG, Evans Jr DJ, Tjoa WS, DuPont HL. Detection and characterization of colonization factor of enterotoxigenic Escherichia coli isolated from adults with diarrhea. Infect Immun 1978; 19: 727-36.

18 Lindahl $M$, Faris A, Wadström T, Hjertén S. A new test based on 'salting out' to measure relative surface hydrophobicity of bacterial cells. Biochim Biophys Acta 1981; 677: 471-6.

19 Markwell MAK. A new solid state reagent to iodinate proteins. Anal Biochem 1982; 125: 427-32.

20 Ljungh $\AA$, Emödy L, Steinrück H, Sullivan PB, West B Zetterberg E, et al. Fibronectin, vitronectin and collagen binding to Escherichia coli of intestinal and extraintestina origin. Int 7 Med Microbiol 1990; 274: 126-34.

21 Ljungh $\AA$, Emödy L, Aleljung P, Olusanya O, Wadström T. Growth conditions for the expression of fibronectin collagen type I, vitronectin and laminin binding to 
Escherichia coli strain NG7C. Current Microbiology 1991; 22: 97-102.

22 Wiström J, Gentry LO, Palmgren A-C, Price M, Nord C-E, Liungh $\AA$ et al. Ecological effects of short-term ciprofloxacin treatment of travellers' diarrhoea Antimicrob Chemother 1992; 30: 693-706.

23 Cravioto A, Tello A, Navarro A, Ruiz J, Villafán H, Uribe F, et al. Association of Escherichia coli $\mathrm{HEp}-2$ adherence et al. Association of Escherichia coli HEp-2 adherence 337: $262-4$.

24 Knutton S, Baldwin T, Williams PH, McNeish AS. Actin accumulation at sites of bacterial adhesion to tissue culure cells. Basis of a new diagnostic test for enteropathogenic and enterohemorrhagic Escherichia coli. Infect Immun 1989; 57: 1290-8.

25 Yatohgo T, Izumi M, Kashiwagi H, Hayashi M. Novel purification of vitronectin for human plasma by heparin affinity chromatography. Cell Struct Funct 1988; 13: 281-92.

26 Vuento $M$, Vaheri A. Purification of fibronectin from plasma by affinity chromatography under non-denaturing plasma by affinity chromatography under
conditions. Biochem $₹$ 1979; 183: 331-7.

27 Cooke EM, Ewins SP, Hywel-Jones J, Lennard-Jones JE. Properties of strains of Escherichia coli carried in difProperties of strains of Escherichia coli carried in dif-
ferent phases of ulcerative colitis. Gut 1974; 15: $143-6$.

28 Schumacher G, Kollberg B, Sandstedt B, Jorup C, Grillner $\mathrm{L}$, Ljungh $\AA$, et al. A prospective study of non-relapsing colitis and first attacks of inflammatory bowel disease. Scand $\mathcal{F}$ Gastroenterol 1993; 28: 1077-85.

$29 \mathrm{Yu}$ J, Kaper JB. Cloning and characterization of the eae gene of enterohæmorrhagic Escherichia coli O157:H7. Mol Microbiol 1992; 6: 411-7.

30 Gulig PA, Curtiss III R. Plasmid-associated virulence of
Salmonella typhimurium. Infect Immun 1987; 55: 2891-901.

31 Dahlbäck B, Podack ER. Characterization of human S protein, an inhibitor of the membrane attack complex of complement. Biochem f 1985; 24: 2368-74.

32 Boyle MDP. Bacterial immunoglobulin-binding proteins I. San Diego: Academic Press, 1990.

33 Kuusela P, Saksela O. Binding and activation of plasminogen at the surface of Staphylococcus aureus. Eur $\mathfrak{F}$ Biochem gen at the surface of

34 Kuusela P, Kaukoranta-Tolvanen S-F, Ullberg M, Kronval G, Saksela O. Surface associated activation of plasminogen on staphylococci and streptococci, and novel mechanisms for bacteriemia to use the activator system of the host. In: Wadström T, Holder IA, Kronvall G, eds. Molecular pathogenesis of surgical infections. Stuttgart: Gustav Fischer Verlag (in press).

35 Ullberg M, Kronvall G, Karlsson I, Wiman B. Receptors for human plasminogen on Gram-negative bacteria. Infect Immun 1990; 58: 21-5.

36 Parkkinen J, Hacker J, Korhonen TK. Enhancement of tissue plasminogen activator-catalyzed plasminogen
activation by Escherichia coli $S$ fimbriæ associated with neonatal septicæmia and meningitis. Thromb Hamost neonatal septicæmi

37 Herrman M, Suchard SJ, Boxer LA, Waldvogel FA, Lew PD. Thrombospondin binds to Staphylococcus aureus and promotes staphylococcal adherence to surfaces. Infect Immun 1991; 59: 279-88.

38 Rose PE, Armour JA, Williams CE, Hill FGH. Verotoxin and neuraminidase induced platelet aggregation activity in premolytic urremic syndrome 7 Clin Pathol 1985; 438-41. 